\title{
Analysis of Faunal Remains from Selected Contexts at the Shelby Mound Site (41CP71): Results from Mound Excavations
}

LeeAnna Schniebs

Unknown

Timothy K. Perttula

Heritage Research Center, Stephen F. Austin State University

Follow this and additional works at: https://scholarworks.sfasu.edu/ita

Part of the American Material Culture Commons, Archaeological Anthropology Commons, Environmental Studies Commons, Other American Studies Commons, Other Arts and Humanities Commons, Other History of Art, Architecture, and Archaeology Commons, and the United States History Commons

Tell us how this article helped you.

This Article is brought to you for free and open access by the Center for Regional Heritage Research at SFA ScholarWorks. It has been accepted for inclusion in Index of Texas Archaeology: Open Access Gray Literature from the Lone Star State by an authorized editor of SFA ScholarWorks. For more information, please contact cdsscholarworks@sfasu.edu. 


\section{Analysis of Faunal Remains from Selected Contexts at the Shelby Mound Site (41CP71): Results from Mound Excavations}

\section{Creative Commons License}

\section{(c) (1) \&}

This work is licensed under a Creative Commons Attribution-NonCommercial 4.0 International License 


\title{
Analysis of Faunal Remains from Selected Contexts at the Shelby Mound Site (41CP71): Results from Mound Excavations
}

\author{
LeeAnna Schniebs and Timothy K. Perttula
}

\section{INTRODUCTION}

Additional faunal material from earlier mound deposits at the Titus phase Shelby Mound site (41CP71) on Greasy Creek in Camp County, Texas (see Perttula, this volume), total 459 faunal specimens, weighing 339.8 grams. Sixty-one (13.3\%) bone fragments are identifiable, and 201 specimens are burned (43.8\%). Standard zooarchaeological identification techniques have been employed in this analysis, using comparative skeletal collections. Attributes that have been examined for each of the bone fragments include taxon, element, and portion of that element, symmetry, burning, and weight. This analysis focuses on identifying general preferences of animal exploitation at this site during the Late Caddo Titus phase. Table 1 summarizes the results of analysis.

Table 1. Summary of taxonomic recovery from the Shelby Mound site.

\begin{tabular}{lrrrrr}
\hline Taxon & NISP & MNI & Habitat* & Percent & No. Burned \\
\hline Vertebrata (indeterminate) & 65 & - & - & 14.2 & 21 \\
Osteichthyes (fish) & 2 & 1 & $\mathrm{~A}$ & 0.2 & 1 \\
Box turtle (Terrapine sp.) & 3 & 1 & W, B & 0.7 & 1 \\
Indeterminate turtle (Testudinata) & 9 & - & - & 2.0 & 7 \\
Turkey (Meleagris gallopavo) & 1 & 1 & WE & 0.2 & - \\
Cottontail (Sylvilagus sp.) & 14 & 2 & WE, B & 3.1 & 2 \\
Squirrel (Sciuridae) & 6 & 1 & W, B & 1.3 & 3 \\
Pocket gopher (Geomys sp.) & 1 & 1 & S & 0.2 & - \\
White-tailed deer & 25 & 1 & WE & 5.4 & 1 \\
(Odocoileus virginianus) & 174 & - & - & 38 & 73 \\
Mammal & 21 & - & - & 4.6 & 15 \\
(size indeterminate) & 138 & - & - & 30.1 & 77 \\
Mammal (small Mammalia) & 459 & 8 & - & 100 & 201 \\
Mammal (large Mammalia) & & & & \\
\hline Total & & & & & \\
\hline
\end{tabular}

*NISP=number of identified specimens, MNI=minimum number of individuals.

Preferred Habitat (Davis 1978): A=aquatic (rivers, swamps, marshes); WE=wooded edges (open meadows, parkland), $\mathrm{W}=$ woodlands (deciduous or pine forests), $\mathrm{B}=$ bottomlands (riparian habitats), $\mathrm{S}=$ sandy soils (alluvium).

A $10 \times 10$ foot unit was excavated in the mound and then divided into four $5 \times 5$ foot squares: A, B, C, and D. The faunal remains were recovered from four levels in two squares in a ca. A.D. 1430-1500 mound deposit, including post holes, pit wall fall, post molds, and a second house at the base of the mound (Level 11) in Square D. In Square A, Segments A and B each represent approximately half of the $5 \times 5$ foot square. Square A is treated as miscellaneous faunal remains that are most likely associated with earlier mound deposits; only 37 fragments were recovered from Square A. The remaining 422 specimens came from Square 
D. Previous analyses of the fauna from the mound deposits focused on more than 3,300 pieces of bone recovered from all four squares (see Schniebs 2004). Table 2 lists the distribution of the faunal remains from this recent collection by area.

Table 2. Distribution of additional faunal remains by provenience from the Shelby Mound site.

\begin{tabular}{llcr}
\hline Provenience & Taxon & NISP & Total NISP \\
\hline Square A, Segment B & unidentifiable & 1 & \\
& small mammal & 3 & 27
\end{tabular}

Square A, Segment C

Square D, Level 7

Square D, Level 9

Square D, Level 10

*Square D, Level 11 unidentifiable

large mammal

unidentifiable

unidentifiable

box turtle

turtle

cottontail

squirrel

pocket gopher

deer

indeterminate mammal

small mammal

large mammal

turtle

cottontail

squirrel

deer

indeterminate mammal

small mammal

large mammal

unidentifiable

turkey

cottontail

deer

small mammal

large mammal
1

9

1

11

3

3

2

4

1

6

22

14

69

135

6

3

2

10

147

2

7

42

1

2

3

2

24

74

unidentifiable

cottontail

4

6

10

Square D, Level 11;

West wall pit (fine screen)

unidentifiable 
Table 2. Distribution of additional faunal remains by provenience from the Shelby Mound site, cont.

\begin{tabular}{llcc}
\hline Provenience & Taxon & NISP & Total NISP \\
\hline & deer & 4 & \\
& indeterminate mammal & 5 & \\
& large mammal & 6 & \\
Square D, post mold, & & & 3 \\
West wall & cottontail & 1 & \\
& deer & 2 & \\
\hline
\end{tabular}

* Level 11 is associated with a house at the base of the mound.

In general, the sample is fairly well preserved, albeit fragmented. The high rate of fragmentation and the amount of unburned fragments suggests that the faunal material may have been boiled for bone grease. The bones are small, broken pieces from larger elements and boiled in water to extract the marrow. The floating fat is then skimmed from the top of the pot and used for frying and other culinary purposes. This method has been well documented over time and used by many different cultures (Leechman 1951:355).

The bones recorded as indeterminate mammal $(n=174)$ dominate the sample and are of mixed size, comprised of the fragmented remains of medium and small mammals. The large mammal $(n=138)$ bone fragments are most likely deer, as deer was one of the main sources of protein in the Caddo diet. Deer ( $n=25)$ is the dominant identifiable animal, followed by cottontail $(n=14)$, and indeterminate turtle $(n=9)$; fish, box turtle, turkey, squirrel, and pocket gopher all have totals ranging from one to nine pieces each. Table 3 lists the elements from the identifiable faunal remains.

Table 3. Composition of identified elements in the Shelby Mound faunal collection.

\begin{tabular}{lll}
\hline Taxon & Element & $\mathrm{N}$ \\
\hline small fish & vertebra & 2 \\
box turtle & shell fragment & 3 \\
indeterminate turtle & shell fragment & 8 \\
turkey & femur fragment & 1 \\
cottontail & radius fragment & 1 \\
& cranial fragment & 1 \\
& maxilla & 1 \\
& teeth & 4 \\
& clavicle & 1 \\
& scapula fragment & 3 \\
pelvis fragment & 1 \\
ulna fragment & 1 \\
& tibia fragment & 1 \\
& cuboid & 1 \\
& mandible fragment & 1 \\
& teeth & 2
\end{tabular}


Table 3. Composition of identified elements in the Shelby Mound faunal collection, cont.

\begin{tabular}{lll}
\hline Taxon & Element & $\mathrm{N}$ \\
\hline pocket gopher & scapula fragment & 1 \\
deer & bulla & 1 \\
& teeth & 3 \\
& tooth fragment & 2 \\
& rib fragment & 6 \\
& vertebra fragment & 2 \\
& pelvis fragment & 1 \\
& humerus fragment & 1 \\
& radius fragment & 2 \\
& femur fragment & 2 \\
& tibia fragment & 2 \\
& metapodial fragment & 1 \\
\hline \multirow{2}{*}{ Total Identifiable Bone } & phalanx & 1 \\
\hline
\end{tabular}

Despite the high quantity of unidentifiable faunal remains and severe fragmentation, several conclusions can be made about this Shelby Mound faunal sample. The fish vertebrae indicate that the site is located near a water source (i.e., Greasy Creek), and that aquatic habitats were exploited. The specimens are from a very small fish (minnow-size). The Caddo were known to use trotlines, a method almost identical to those currently used today (Newcomb 1993). The box turtle suggests the exploitation of woodlands and bottomlands. The box turtle is a slow-moving animal and is easily caught when the occasion arises by passive hunting methods, often by women or children. The unidentifiable turtle shell fragments compare favorably in size to box turtle or musk/mud turtle, confirming Caddo hunting activities in aquatic and/or woodland and bottomland habitats. The turkey bone as well as the deer remains suggests the hunting of wooded edges. One of the deer teeth is from an individual approximately seven months of age at time of death; this deer was killed in the late summer since fawns are born in the early spring. A second deer tooth has very slight wear and one femur is unfused, which is also evidence of an immature animal. Several other deer elements appear to be from an older individual based on their size and the fused epiphyses on the long bones. Deer disarticulation and butchering is suggested by cut marks on an astragalus, a small, dense bone in the lower leg. Most of the unidentifiable large mammal bone fragments are very likely from deer. There are a minimum of two cottontail rabbits in this faunal assemblage, based on the recovery of two right scapula fragments. The larger size of at least two elements suggests that at least one of these rabbits is a swamp rabbit (S. aquaticus); swamp rabbits prefer bottomlands. The unidentifiable small mammal bones could be from cottontail, squirrel, pocket gopher, or any other small rodent as these are common in Caddo faunal assemblages. The indeterminate vertebrate remains could represent any taxonomic class.

In summary, the faunal material in this collection is indicative of the Caddo exploitation of the rich habitats of the Pineywoods in East Texas in the $15^{\text {th }}$ and early $16^{\text {th }}$ centuries A.D.; the remains are dietary debris. Further investigations at the Shelby Mound site could provide additional information as to the subsistence preferences and animal hunting activities of Caddo peoples during the Titus phase. 


\section{COMPARISON OF TITUS PHASE FAUNAL ASSEMBLAGES}

\section{Timothy K. Perttula}

Among the more common vertebrate species identified in post ca. A.D. 1430 Titus phase assemblages in the Big Cypress and Sabine River basins in East Texas are deer, turkey, cottontail rabbit, jackrabbit, squirrel, small rodents, and beaver, along with the domestic dog (see Fields and Gadus 2012; Nelson and Perttula 2003; Parsons 2011; Perttula et al. 1982; Perttula and Sherman 2009; Schniebs 2004, 2013). Two Titus phase sites in the Little Cypress Creek basin also have bison skeletal remains (Parsons 2011), indicating some exploitation of prairie habitats to the northwest and west of Caddo settlements in the Pineywoods.

Turtle and fish are also present in Titus phase sites, and they were obviously gathered and eaten, but they are apparently relatively uncommon compared to the mammals and birds in the diets of these Caddo peoples. The limited recovery of fish bones may be due in part to poor preservation of faunal remains in Pineywoods sites as well as the limited use of flotation and fine-screening to recover the smaller animal bones. Fish and turtle are relatively abundant at the Shelby site (41CP71) on Greasy Creek (ca. 3\% of the identified specimens) and the Underwood site (41CP230) on Big Cypress Creek, including gar, freshwater drum, and medium-sized bony fish (Nelson and Perttula 2003; Schniebs 2004).

The largest and perhaps most representative faunal assemblage (ca. 10,000 specimens) from Titus phase contexts is from the Rookery Ridge site (41UR133) in the Little Cypress Creek basin (Parsons 2011). Among the faunal remains are four species of birds - including migratory waterfowl and turkey - as well as rodents, lizards, alligator, much turtle (emydids and box turtle), 12 mammal species, and dog/coyote. Deer were apparently intensively used at the site, and the bone is apparently the product of the processing and consumption of deer on the site. Other resources that were exploited by this Titus phase group includes gar and catfish. Despite flotation and fine-screening, fish remains comprise less than $3 \%$ of the identifiable remains from the site.

Only about $2 \%$ of the identified fauna from the Pine Tree Mound site (41HS15), another substantial Titus phase faunal assemblage ( $\mathrm{n}=10,326$ specimens), is fish (Fields and Gadus 2012:Table 8.3) Deer and probable deer bones account for almost $78 \%$ of the identified faunal remains in the faunal assemblage, followed by small mammals (11.3\%, including squirrel, rabbit, opossum, raccoon, beaver, etc.), turtles (9.4\%), and birds $(0.2 \%)$.

At the Shelby site, including the present samples discussed above, the same range of faunal remains have been found in its large collection (+4000 specimens) from midden deposits and mound contexts. They include several kinds of fish and reptiles (especially turtle), turkey, and a range of other birds of various sizes, and seven mammal species, among them deer, rabbit, and squirrels (Schniebs 2004:Tables 3 and 4); deer and large mammal remains comprise about $70 \%$ of the identified specimens. These remains are consistent with a diet that relied on large game animals for meat and protein, supplemented by fish (less than $1 \%$ of the identified specimens), turkey, rabbit, and other small mammals.

In general, deer and turkey appear to have been the dominant exploitable animal species for these Caddo peoples. However, a wide range of animals were actually exploited and consumed by Titus phase peoples for meat, as well as sources for tools and other accoutrements (i.e., sinew, hides).

\section{REFERENCES CITED}

Davis, W. B.

1978 The Mammals of Texas. Bulletin No. 41, revised. Texas Parks and Wildlife Department, Austin. 
Fields, R. C. and E. F. Gadus (editors)

2012 Archeology of the Nadaco Caddo: The View from the Pine Tree Mound Site (41HS15), Harrison County, Texas. 2 Vols. Reports of Investigations No. 164. Prewitt and Associates, Inc., Austin.

Leechman, D.

1951 Bone Grease. American Antiquity 16(4):355-356.

Nelson, B. and T. K. Perttula

2003 Archeological Investigations of the Underwood Site (41CP230): A Titus Phase Settlement along Big Cypress Creek in Camp County, Texas. Journal of Northeast Texas Archaeology 17:1-61.

Newcomb, W. W., Jr.

1993 The Indians of Texas. $2^{\text {nd }}$ Edition. University of Texas Press, Austin.

Parsons, $\mathrm{M}$.

2011 Mitigation Phase Archeological Investigations at Lake Gilmer, Upshur County, Texas. MS on file, Archeology Division, Texas Historical Commission, Austin.

Perttula, T. K., C. J. Crane, and J. E. Bruseth

1982 A Consideration of Caddoan Subsistence. Southeastern Archaeology 1(2):89-102.

Perttula, T. K. and D. L. Sherman

2009 Data Recovery Investigations at the Ear Spool Site (41TT653), Titus County, Texas. Document No. 070205. PBS\&J, Austin.

Schniebs, L.

2004 Animal Bones Recovered from 41CP71, Shelby Mound and Village Areas. In Archeological Investigations at the Shelby Site (41CP71) on Greasy Creek, Camp County, Texas, by T. K. Perttula and B. Nelson, pp. 65-133. Special Publication No. 5. Friends of Northeast Texas Archaeology, Pittsburg and Austin.

2013 Analysis of Faunal Remains from the Sam D. Carpenter Bottom Site (41CP495). Journal of Northeast Texas Archaeology 42:18-20. 